\title{
Warm Autoimmune Hemolytic Anemia: A Clinical Model to Study Mechanisms of Immunoregulation*
}

\author{
Dorothea Stahl \\ Institute for Transfusion Medicine, University of Münster, Münster, Germany
}

\section{Key Words}

Self-tolerance $\cdot$ Natural autoreactivity · Warm autoimmune hemolytic anemia - Immunoregulation . Immune complex

\section{Summary}

The study of immune hemolytic anemias has contributed significantly to the understanding of the immune response in the human system in the past. Thus, the concept of receptor specificity - becoming the rationale of the clonal selection theory when trying to explain how the organism avoids autoaggression - has been developed originally upon the study of immune hemolytic anemias, and the question whether the antigen-antibody reaction is determined primarily by chemical or by physical aspects of interaction of molecules has been discussed originally taking immune hemolytic anemias as an example. Today, immunohematology still provides excellent models to study immune mechanisms that are of both clinical relevance and fundamental significance for the understanding of mechanisms that determine the appropriate recognition of self- and non-self-antigens in the context of complex dynamic interactions at the cellular and humoral level of the human immune system. The data summarized in this review focus on the aspects that the study of warm autoimmune hemolytic anemia may contribute to the understanding of immunoregulation in the human system.

\section{Generating and Maintaining Self-Tolerance}

That autoreactivity is equivalent to autoaggression and therefore forbidden under physiological conditions has been a cen-

*Dedicated to Prof. Dr. Peter Hanfland, Bonn, on the occasion of his 65th birthday.

\author{
Schlüsselwörter \\ Immuntoleranz · Natürliche Autoreaktivität . \\ Wärmeautoimmunhämolyse · Immunregulation · \\ Immunkomplex
}

\section{Zusammenfassung}

Wesentliche Konzepte zum Verständnis immunologischer Mechanismen wie das Konzept der Rezeptorspezifität - die Grundlage der klonalen Selektionstheorie wurden in der Vergangenheit am Beispiel der Immunhämolysen entwickelt, und grundlegende Diskussionen wie die Diskussion, ob die Antigen-Antikörper-Reaktion primär chemischer oder primär physikalischer Natur ist, wurden bereits zum Ausgang des 19. und zu Beginn des 20. Jahrhunderts am Beispiel der Immunhämolysen geführt. Das Studium der Immunhämolysen ist auch heute noch in hervorragender Weise geeignet, klinisch relevante Fragen mit immunologisch-konzeptionellem Potential exemplarisch anzugehen. Die vorliegende Übersichtsarbeit fasst Daten zusammen, die am Beispiel der Autoimmunhämolyse vom Wärmetyp zeigen, wie die Immunhämatologie zum heutigen Verständnis immunregulatorischer Mechanismen beitragen kann. tral dogma of immunology since Paul Ehrlich established the concept of the 'Horror autotoxicus': An autotoxin that may destroy the cells of the organism that originally formed it does not exist under physiological conditions [1-3]. Karl Landsteiner's observation that plasma of healthy individuals contains natural antibodies directed exclusively at ABO blood group antigens that the individual's red blood cells do not express,

\begin{tabular}{ll}
\hline KARGER & @ 2006 S. Karger GmbH, Freiburg \\
Fax +49 7614520714 & Accessible online at: \\
$\begin{array}{l}\text { E-mail Information@Karger.de } \\
\text { www.karger.com }\end{array}$ & www.karger.com/tmh
\end{tabular}


gave strong support to Ehrlich's concept of a 'Horror autotoxicus' and became the rationale for compatible red blood cell transfusion [4].

Since Burnet and Medawar published their groundbreaking work, it is widely accepted that deletion of autoreactive lymphocyte clones underlies immunotolerance [5-7]. Deletion of autoreactive lymphocyte clones occurs during lymphocyte development at a structural level (i.e. central tolerance, achieved by receptor editing or apoptosis of self-reactive clones). Once lymphocyte maturation is complete but has resulted in the formation of autoreactive lymphocytes that have escaped central tolerance mechanisms, immunotolerance is achieved in the periphery mainly at a functional level by a variety of mechanisms that render autoreactive cells anergic - although recent evidence in mice indicates that receptor editing may still occur in mature antigen-activated peripheral lymphocyte populations [8-16].

However, immunotolerance - seen from the angle of a functional concept - results from a variety of additional regulatory mechanisms in the context of complex interactions at the cellular and humoral level of the human immune system: Complement proteins are involved in the selection of B cells [17]. The outstanding significance of CD4+ CD25+ regulatory $\mathrm{T}$ cells - not yet fully understood in its different subsets for the generation of immunotolerance has become clear during the last decade [18-24]. Dendritic cell homeostasis is central to the regulation of self-reactivity [25-26], although views differ on the molecular details [27-31]. Furthermore, the interaction of $\mathrm{T}$ cells and macrophages as well as selfversus non-self-discrimination by natural killer (NK) cells in particular in the setting of pro-inflammatory conditionspoints to a close linkage between functions of innate and adaptive immunity when it comes to maintaining immunotolerance $[32,33]$. Likewise, immunoglobulins use a variety of mechanisms to regulate immunotolerance, involving $\mathrm{F}(\mathrm{ab})_{2}$ regions, $\mathrm{Fc}$ regions, isotypes and immunoglobulin subclass-dependent functions, as well as the capability to penetrate the membrane of living cells and exert intracellular functions [34-47].

\section{Natural Autoreactivity Contributes to the Maintenance of Self-Tolerance}

Already in 1900, Ehrlich's concept of the 'Horror autotoxicus' was opposed by members of the group around Elie Metchnikoff who observed the existence of autoantibodies under physiological conditions and suggested the concept of autoimmunization [48, 49]. The concept of autoreactivity existent under physiological conditions has subsequently been taken up by the team of Niels Jerne [50-55] and that of Irun Cohen [56-60]. Meanwhile, it is established knowledge that autoreactive $\mathrm{T}$ cells, $\mathrm{B}$ cells and antibodies (i.e. natural autoantibodies) are present under physiological conditions, and are of substan- tial significance for the generation and maintenance of immunotolerance [61-75].

The critical time period for establishing natural tolerance toward self-antigens is the fetal and perinatal period, and it is widely dependent on a functional thymus [54-76]. Once established, immunotolerance must be maintained throughout life. Although scientific evidence indicates that plasma cells as well as B and T memory cells may be characterized by a significantly longer survival period and may therefore contribute much more efficiently to the maintenance of immunological memory than originally assumed [77-81], there is a constant need to educate newly developing lymphocytes in the process of differentiation of hematopoietic progenitor cells to discriminate self and non-self, throughout life and despite of thymus involution [54]. How does the organism meet this challenge, in particular with regard to the maintenance of natural autoreactivity?

A genetically determined natural autoreactivity, active at the onset of development of natural tolerance toward the immunological self, would implement an outlasting internal image of the immunological self. Such an internal image would allow newly developing lymphocytes to align throughout life with the original demand on how to define self. Such genetically determined natural autoreactivity requires that $\mathrm{T}$ lymphocytes as well as B lymphocytes are selected for survival during their development at the basis of their autoreactivity (i.e. by positive selection) and are maintained in an active state on the basis of their autoreactivity. Current experimental data indeed point to the existence of a genetically determined natural autoreactivity at the onset of self-tolerance [54, 82-87]. Positive selection of $\mathrm{T}$ cells, tightly regulated by the affinity of the TCR for self-antigen, characterizes T cell development in fetal and perinatal life [88]. Recent evidence in mice indicates that self-reactive $\mathrm{B}$ cells may undergo positive selection due to recognition of self-antigen, proliferate in the presence of the corresponding self-antigen and are maintained on the basis of their self-reactivity [67]. In the periphery, such a genetically determined internal image of self may be mediated by natural autoantibodies ('the immunological homunculus') $[56,89,90]$.

Repertoires of human naturally self-reactive antibodies have been intensively investigated during the last decade [72, 91]. Natural self-reactive antibody repertoires are directed toward a limited subset of immunodominant autoantigens, arise early in development and remain conserved throughout the aging process [92-96]. The selection of natural self-reactive IgG antibody repertoires requires normal interaction between $\mathrm{T}$ and B cells $[97,98]$. Although the epitopes participating in the selection of human natural self-reactive $B$ cells have not been identified yet, it has been shown that many self-molecules with immunoregulatory function - such as CD4, CD5, MHC class I molecules, Fc $\gamma$ receptors, idiotypes of antibodies and of surface immunoglobulin on B cells, and parts of the TCR are recognized by natural autoantibodies [72]. Natural self-re- 
active antibodies regulate immune responses by several mechanisms [72]. Such mechanisms include the interference with the selection of B cell repertoires $[41,42,99,100]$ - depending at least in part on antibody variable regions [41] - and the control of the proliferation of CD4+ T cells specific for autoantigens recognized by natural autoantibodies [101]. Natural autoantibody repertoires of $\mathrm{IgM}$ and/or IgG are altered in a variety of autoimmune disorders, immunodeficiency syndromes and lymphoproliferative diseases [91], and intravenous immunoglobulin (IVIg) - a therapeutic preparation of pooled normal poly-specific human IgG obtained from large numbers of healthy blood donors that contains homologous immune antibodies as well as homologous natural autoantibodies - has been shown to prevent or attenuate autoimmune diseases efficiently in the experimental as well as in the clinical setting [41, $72,102]$. Taken together, scientific evidence indicates that natural autoreactivity, present and active under physiological conditions, contributes significantly to the generation and maintenance of immunotolerance in the human system.

\section{Warm Autoimmune Hemolytic Anemia: Dysregulation of Natural Autoreactivity Contributes to Disease}

The same mechanisms that generally contribute to immunotolerance are supposed to account for self-tolerance toward red blood cells (RBC), although development of self-tolerance toward $\mathrm{RBC}$ under physiological conditions in the human system has not been investigated in particular. Intensive research in the past 10 years, however, has led to an altered understanding of components of RBC membranes, such as blood group antigens, which are now appreciated as biomolecules with functional significance [103]. Within this context, components of RBC membranes, such as the cell surface glycoprotein CD47 (integrin-associated protein/IAP), linking the interaction of band 3 complex and the $\mathrm{Rh}$ complex in the maintenance of RBC membrane integrity, have also gained attention as markers of self $[104,105]$. Thus, a decreased expression of CD47 on murine RBC has been described to be involved in enhanced extravascular clearance of RBC, possibly by altered CD47-SIRP $\alpha$ interactions [106]. Natural autoantibodies against RBC do exist. They are directed toward structures of the RBC membrane and the cytoskeleton, and in recent years it has been demonstrated that natural autoantibodies against $\mathrm{ABO}$ blood group antigens exist in the plasma of healthy individuals [107-109].

In warm autoimmune hemolytic anemia (WAIHA), self-tolerance toward RBC is broken. WAIHA accounts for $50-70 \%$ of cases of autoimmune hemolytic anemia [110], and is characterized by the occurrence of antibodies binding to RBC. Autoantibodies are typically of polyclonal origin, belong to the $\mathrm{IgG}$ isotype and arise idiopathically or in the context of lymphoproliferative disorders or other autoimmune diseases.
IgG-coated RBC undergo accelerated Fc $\gamma$ receptor mediated extravascular clearance $[111,112]$. The mechanisms of Fc $\gamma$ receptor mediated clearance of IgG-coated RBC have been studied intensively [45, 113-118], with research focussing on the effector mechanisms resulting in RBC destruction. Mechanisms at the origin of broken tolerance toward $\mathrm{RBC}$ in human WAIHA remain unclear. The typical approach to understand an autoimmune disease is to analyze the nature of the autoantigen and to investigate the effector mechanisms finally resulting in tissue destruction. Whereas the effector mechanisms leading to RBC destruction in WAIHA became evident very quickly, the characterization of the autoantigens has proved to be more difficult. Although some RBC structures, such as rhesus antigens, glycophorin A or the band 3 structure, may be particularly recognized by autoantibodies, a review of the literature reveals that nearly every RBC antigen characterized by serological studies has been described as target structure in WAIHA [112,119-121]. In addition, warm autoantibodies typically 'broaden' their specificities and show reactivity with autologous and allogeneic RBC [112]. Autoantibodies eluted from autologous RBC have been described that have a well-defined specificity, although the patient's RBC lacked the corresponding antigen [122]. Such antibodies can be absorbed by RBC both positive and negative for the corresponding antigen. The nature of the epitopes against which such mimicking antibodies are directed is yet unclear [111, 112]. The specificity of RBC-bound IgG fails to discriminate between natural and WAIHA-related autoreactivity of IgG toward RBC [123]. Overall, investigations to characterize the autoantigen in WAIHA did not yet reveal a general recognition pattern of antibodies on the RBC membrane.

Natural IgM critically contributes to the maintenance of selftolerance [100, 124, 125]. Experimental models indicate that deficient serum IgM predisposes to the development of IgGmediated autoimmune diseases [126-128]. In 1994, first data appeared indicating that a dysregulated control of natural autoantibodies might be involved in the pathophysiology of spontaneous autoimmune hemolytic anemia of NZB mice [129]. So does a failure of control of natural anti-RBC specific IgG contribute to development of warm autoimmune hemolytic anemia in humans?

Choosing an approach of screening antibody reactivities in complex antibody mixtures, such as serum, toward a large panel of antigens derived from tissue extracts by quantitative immunoblotting, followed by interpretation of the data by multiparametric statistical analysis using principal component analysis and linear discriminant analysis, it could be demonstrated that self-reactive antibody repertoires of IgG purified from plasma and of IgG purified from RBC eluates do not differ between healthy donors and patients with IgG-mediated WAIHA. In contrast, autoreactive repertoires of the patients' IgM exhibit broadly altered patterns of reactivity compared to those of healthy controls $[130,131]$. IgG purified from eluates of RBC of healthy donors agglutinate RBC to a similar 


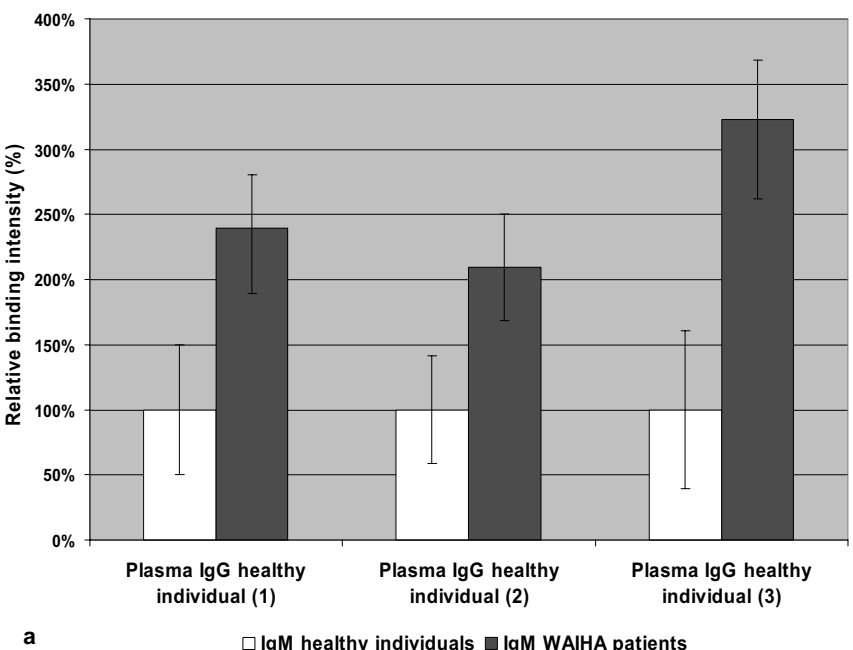

$p=0.024$

$p=0.001$ *

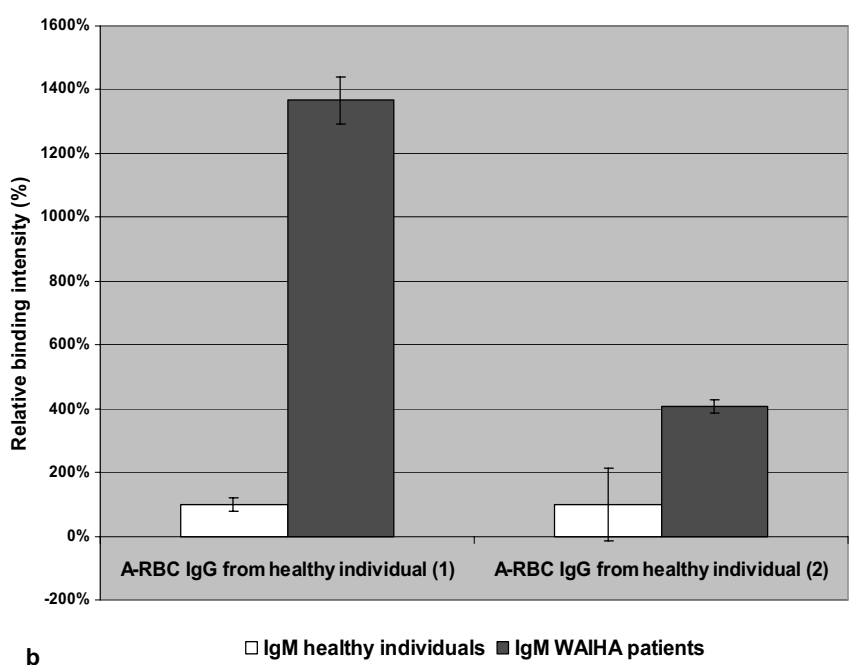

Fig. 1. Surface plasmon resonance analysis of binding affinities of IgM of WAIHA patients toward normal IgG. The binding affinities of IgM purified from plasma of 5 WAIHA patients toward a IgG purified from plasma of 3 different healthy individuals and toward $\mathbf{b}$ anti-RBC IgG purified from RBC eluates of 2 different healthy individuals were compared with the binding affinities of $\operatorname{IgM}$ purified from plasma of 5 healthy individuals. The figure depicts the mean relative binding intensities \pm standard deviation of $\operatorname{IgM}(150 \mu \mathrm{g} / \mathrm{ml})$ of WAIHA patients in comparison to the mean binding intensities \pm standard deviation of $\operatorname{IgM}(150 \mu \mathrm{g} / \mathrm{ml})$ of healthy individuals (mean, healthy individuals $=100 \%$ ). A p value of $\leq 0.05$ was considered to represent differences of statistical significance.

Reprinted from Stahl D, Sibrowski W: Warm autoimmune hemolytic anemia is an immune complex disease. J Autoimmun 2005;25(4):272-282, with permission from Elsevier Inc.

extent as $\mathrm{IgG}$ purified from eluates of $\mathrm{RBC}$ of patients with WAIHA. However, the agglutinating ability of $\mathrm{IgG}$ in RBC eluates is suppressed in unfractionated eluates of RBC of healthy donors, whereas it can be readily found in unfraction-

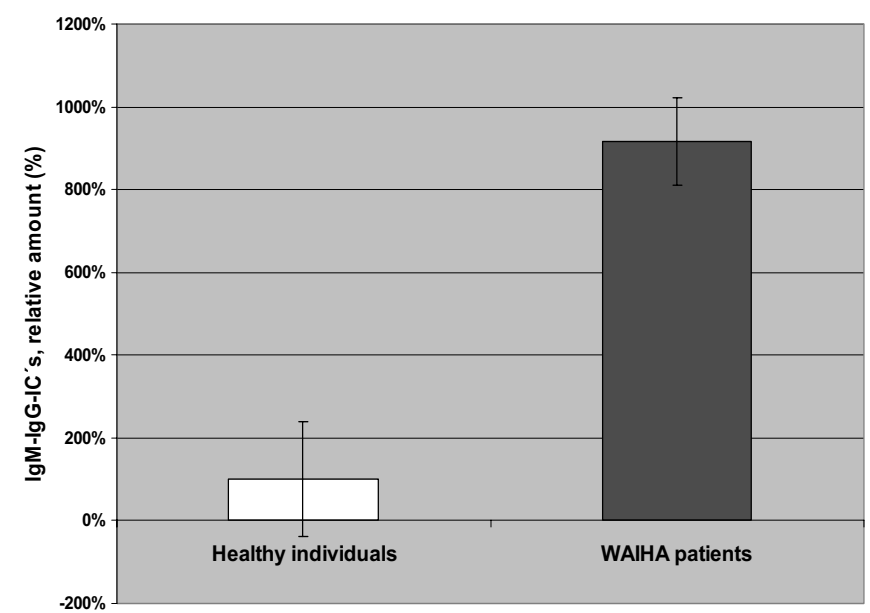

Fig. 2. Plasma of WAIHA patients contains an enhanced amount of IgM-IgG immune complexes. IgM was purified from plasma of WAIHA patients $(\mathrm{n}=15)$ and healthy individuals $(\mathrm{n}=15)$ and analyzed for $\operatorname{IgG}$ content. The figure depicts the content of IgM-IgG immune complexes within purified IgM. Given are mean contents \pm standard deviation for WAIHA patients in comparison to mean contents \pm standard deviation for healthy individuals (mean, healthy individuals $=100 \%$ ). A p value $\leq 0.05$ was considered to represent differences of statistical significance.

Reprinted from Stahl D, Sibrowski W: Warm autoimmune hemolytic anemia is an immune complex disease. J Autoimmun 2005;25(4):272-282, with permission from Elsevier Inc.

ated eluates of RBC of patients. Non-IgG molecules, including $\operatorname{IgM}$, are essential in controlling the agglutinating capability of IgG in unfractionated RBC eluates. Taken together, these observations indicate that anti-RBC IgG autoantibodies of patients with WAIHA share extensive similarity with natural anti-RBC autoantibodies of healthy donors, suggesting that a defective control of IgG autoreactivity by autologous IgM is an underlying mechanism for autoimmune hemolysis in WAIHA [130].

\section{Warm Autoimmune Hemolytic Anemia is an IgM-IgG Immune Complex Disease}

Recent data indicate that altered IgM-IgG immune complexes are at the origin of such altered antibody repertoire of plasma IgM of WAIHA patients [132]. IgM in plasma of WAIHA patients exhibits a significantly increased binding affinity toward IgG purified from plasma of healthy individuals and eluted from the RBC surface of healthy individuals, compared to the binding affinity of $\operatorname{IgM}$ of healthy individuals (fig. $1 \mathrm{a}, \mathrm{b}$ ), resulting in a significantly higher amount of $\operatorname{IgM}-\operatorname{IgG}$ immune complexes in plasma of WAIHA patients than in plasma of healthy individuals (fig. 2). The occurrence of an enhanced amount of IgM-IgG immune complexes in plasma of WAIHA patients is independent of the etiology of the disease and can 
Fig. 3. Pathophysiological model of WAIHA. The original pathological event in WAIHA is a disturbed balance between IgM specific for $\operatorname{IgG}$ (i.e. anti-IgG IgM) and IgG. The disturbed balance of $\operatorname{IgM}-\mathrm{IgG}$ interactions starts at the level of secretion of altered anti-IgG IgM (1.). Such altered anti-IgG IgM is characterized by an enhanced affinity for normal IgG. Future investigations on anti-IgG IgM at the molecular level will clarify the structural basis for the enhanced affinity of IgM for normal IgG. The secretion of altered anti-IgG IgM results in loss of control of IgM over the level of proliferation of $\operatorname{IgG}$ secreting B cells, thereby withdrawing these $\mathrm{B}$ cells from the efficient control by anti$\operatorname{IgG} \operatorname{IgM}$ (2.). Proliferation of IgG secreting B cells leads to the enhanced formation of soluble IgM-IgG immune complexes (2.). Such IgMIgG immune complexes adhere to RBC via the $\mathrm{IgG}$ component of the immune complex (2.). Binding of IgM-IgG immune complexes to $\mathrm{RBC}$ via the $\mathrm{IgG}$ component is most likely to occur via the Fab fragments of IgG of the immune complex, i.e. via RBC antigen specific binding. This mechanism implies that the $\mathrm{IgG}$ secreting B cells exhibit specificity of the BCR for RBC structures (2.). IgG coated RBC are recognized by Fc $\gamma$ receptor bearing macrophages and cleared from the circulation resulting in extravascular hemolysis (3.). In order to depict this concept plastically, the IgM BCR is shown as a pentamer, and not as a monomeric molecule.Reprinted from Stahl D, Sibrowski W: Warm autoimmune hemolytic anemia is an immune complex disease. J Autoimmun 2005;25(4):272-282, with permission from Elsevier Inc.

be observed in primary WAIHA as well as in secondary WAIHA. IgM-IgG immune complex formation in plasma might simply represent an epi-phenomenon of WAIHA. However, several lines of evidence suggest that IgM-IgG immune complexes in plasma of WAIHA patients primarily contribute to the disease: 1 . IgG1 and IgG3 are actively enriched in IgM$\mathrm{IgG}$ immune complexes in plasma of WAIHA patients, in accordance with IgG subclasses typically detected onto the RBC surface of WAIHA patients [123]. 2. IgM-IgG immune complexes are present in the immunglobulin fraction eluted from RBC of patients with WAIHA. 3. IgM in plasma of WAIHA patients exhibits binding affinity to $\mathrm{Fc}$ fragments as well as toward $\mathrm{F}(\mathrm{ab})_{2}$ fragments derived from IVIG, whereas IgM derived from $\mathrm{RBC}$ eluates from WAIHA patients binds preferentially to $F(a b)_{2}$ fragments of IVIG, suggesting active enrichment of altered IgM-IgG immune complexes onto the RBC membrane. To understand how an enhanced IgM-IgG immune complex formation may originally contribute to antiRBC autoimmunity in WAIHA, the following hypothetical model may be taken as a basis for aligning future experimental work in this field (fig. 3). The original pathological event in WAIHA is a disturbed balance between IgM specific for IgG (i.e. anti-IgG IgM) and IgG. The disturbed balance of IgM$\mathrm{IgG}$ interactions starts at the level of secretion of altered anti$\operatorname{IgG} \operatorname{IgM}$ (fig. 3 , 1.). Such altered anti-IgG $\operatorname{IgM}$ is characterized by an enhanced affinity for normal IgG. Future investigations on anti-IgG $\operatorname{IgM}$ at the molecular level will clarify the structural basis for the enhanced affinity of IgM for normal $\mathrm{IgG}$. The secretion of altered anti-IgG IgM results in loss of control of IgM over the level of proliferation of IgG secreting B cells, thereby withdrawing these B cells from the efficient control by anti-IgG IgM (fig. 3, 2.). Antibody-mediated feedback regulation of antibody production has been principally described as a regulatory mechanism of $\mathrm{B}$ cell proliferation $[133,134]$ and might be operating not only at the IgG-Fc $\gamma$ RIIB level, but also at an IgM-Fc $\mu$ R level. A Fc receptor for IgM, constitutively expressed by the majority of B lymphocytes, has been described recently [135]. Proliferation of IgG secreting B cells leads to enhanced formation of soluble IgMIgG immune complexes. Such IgM-IgG immune complexes adhere to RBC via the IgG component of the immune complex (fig. 3, 2.). IgG coated RBC are recognized by Fc $\gamma$ receptor bearing macrophages and cleared from the circulation resulting in extravascular hemolysis (fig. 3,3 .).

\section{The Impact of Immune Complexes on the Regulation of Immune Responses}

Taken together, altered IgM-IgG immune complexes in plasma and associated with the RBC membrane are the characteristic feature of WAIHA, independent of the etiology of the disease. The data suggest that not the RBC itself but autologous immunoglobulin of isotype $\operatorname{IgG}$ with a specificity for 
RBC structures might be the autoantigen in WAIHA [132]. To identify the epitope specificity of $\operatorname{IgM}$ and $\operatorname{IgG}$ within the IgM-IgG immune complexes of WAIHA patients and to characterize the mechanism of immune complex-RBC interaction, is at the center of further investigations. The molecular and structural characterization of IgM of WAIHA patients will be of particular significance for the further understanding of the pathophysiological processes leading to WAIHA. The results of these studies may define targets for therapeutic intervention in WAIHA at a causal disease-specific level.

However, the observation of altered IgM-IgG immune complexes in WAIHA may also be of conceptual interest for the understanding of the impact of immune complexes on the regulation of immune responses. Immune complexes typically consist of antigens bound to antibodies specific for the corresponding antigen. Depending on the immunoglobulin isotype, an immune complex may activate complement. Immune complexes contribute critically to the regulation of normal immune responses toward self- and non-self-antigens under physiological conditions. They mediate increased uptake and processing of antigen by antigen presenting cells [101, 136, 137], influence signal transduction in antigen presenting cells, such as B lymphocytes, by receptor cross-linking [138-140] and may contribute to $\mathrm{T}$ cell tolerance by binding to immature dendritic cells in the absence of co-stimulation [141]. Immune complexes exert immunoregulatory functions by binding to receptor structures, such as Fc $\gamma$ receptors, the B cell receptor (BCR) or complement receptors. IgG2a-chromatin immune complexes in mice activate autoreactive $\mathrm{B}$ cells by synergistic engagement of the BCR and a Toll-like receptor, positioning immune regulation by immune complexes in the central interface of the innate and the adaptive immune systems [142]. Immune complexes consisting exclusively of immunoglobulin molecules, i.e. Ig-Ig immune complexes, may be formed either according to the principles of an idiotype-anti-idiotype reaction [51], or - if the antigenic determinants of the Ig molecule belong to the Fc region of the molecule - represent rheumatoid factors [143]. Ig-Ig immune complexes might use all of the above mentioned mechanisms to shape the immune response.

Besides patients with IgG mediated WAIHA, an enhanced frequency of IgM-IgG immune complexes in plasma has so far been described in patients with Graves' disease and in patients with hepatitis A. A decreased frequency of IgM-IgG immune complexes in plasma has been demonstrated in patients with gastric cancer [144]. In WAIHA patients, IgG3 and IgG1 are actively enriched in IgM-IgG immune complexes, despite of a normal IgG subclass distribution in plasma ( $\operatorname{IgG} 1>\operatorname{IgG} 3>$ IgG $2>\operatorname{IgG} 4$ ) [132]. The IgG subclass distribution in IgMIgG immune complexes of human plasma has not yet been systematically investigated. However, one should expect that the different physicochemical and sterical properties of the various IgG subclasses, which are due to different hinge regions $[145,146]$, favor a selective enrichment of IgG subclasses in IgM-IgG immune complexes under physiological conditions. Such selective enrichment of IgG subclasses in IgM-IgG immune complexes of plasma might differ from the normal $\mathrm{IgG}$ subclass distribution in plasma itself and contribute to the physiological functions of IgM-IgG immune complexes. Taken together, the future structural and functional analysis of IgMIgG immune complexes may reveal novel regulatory mechanisms for immune responses to self-immunoglobulin under physiological conditions in humans. Of particular interest will be the question of how pro-inflammatory conditions contribute to the generation and function of altered IgM-IgG immune complexes, given that such conditions may lead to a subpopulation of anti-F(ab') 2 antibodies that cover a part of the physiologically active Fc domain of their counterpart and are nevertheless able to immobilize the Fab arms $[36,38]$.

\section{Mechanisms of Immunoregulation in WAIHA as a Model to Investigate Regulation of Complex Dynamic Biological Systems}

The data summarized in this review focus on the aspects that the study of warm autoimmune hemolytic anemia may contribute to the understanding of immunoregulation in the human system and demonstrate that immunohematology contributes to transfusion safety much more than diagnostic strategies. Immunohematology provides a conceptual understanding of compatibility underlying diagnostic strategies. Beyond-genome biology strongly indicates that the specificity of functional modules of the immune response contributes to the overall outcome of immune responses. Thus, specificity - and consequently compatibility - may be defined by functional aspects of the immune system in its respective condition as much as by structural components of immune cells and immune receptors. Immunohematology in the context of the current state of the art in medicine and biology still provides excellent models to study mechanisms that are both clinically relevant and of fundamental significance for the understanding of principles of the immune response.

\section{Acknowledgements}

Supported by grants from the Institut National de la Santé et de la Recherche Médicale (INSERM), Montpellier, France, the Central Laboratory of the Swiss Red Cross, Bern, Switzerland, the German Society for Transfusion Medicine and Immunohematology (DGTI), Germany, the Hemotherapy Research Foundation, Germany, the German Research Society (DFG, Az: STA 520/2-1) and the program 'Innovative Medical Research' of the Medical Faculty, University of Münster, Germany. 


\section{References}

1 Ehrlich P, Morgenroth J: Über Hämolysine: Dritte Mitteilung. Berl. Klin Wochenschr 1900;37:453-458 and 681-687.

2 Silverstein AM: The side-chain theory of antibody formation, in Silverstein AM (ed): Paul Ehrlich's receptor immunology: The magnificent obsession. San Diego, Academic Press, 2002, pp 77-94.

3 Silverstein AM: Immune hemolysis: Bordet challenges Ehrlich, in Silverstein AM (ed): Paul Ehrlich's receptor immunology: The magnificent obsession. San Diego, Academic Press, 2002, pp 95-122.

4 Landsteiner K: Über Agglutinationserscheinungen normalen menschlichen Blutes. Wien Klin Wochenschr 1901;14:956-958.

5 Billingham RE, Brent L, Medawar PB: Activity acquired tolerance of foreign cells. Nature 1953;172 (4379):603-606.

6 Burnet FM: The clonal selection theory of antibody formation. London, Cambridge University Press, 1959 .

7 Burnet FM: Immunological recognition of self. Science 1961;133:307-311.

8 Nossal GJ, Pike BL: Evidence for the clonal abortion theory of B-lymphocyte tolerance. J Exp Med 1975;141(4):904-917.

-9 Kappler J, Roehm N, Marrack P: T cell tolerance by clonal elimination in the thymus. Cell $1987 ; 49$ 273-280.

10 Goodnow CC, Crosbie J, Adelstein S, Lavoie TB, Smith-Gill SJ, Brink RA, Pritchard-Briscoe H, Wotherspoon JS, Loblay RH, Raphael K, et al: Altered immunoglobulin expression and functional silencing of self-reactive B lymphocytes in transgenic mice. Nature 1988;334(6184):676-682.

11 Tiegs SL, Russell DM, Nemazee D: Receptor editing in self-reactive bone marrow B cells. J Exp Med 1993;177(4):1009-1020.

- 12 Goodnow CC, Cyster JG, Hartley SB, Bell SE, Cooke MP, Healy JI, Akkaraju S, Rathmell JC, Pogue SL, Shokat KP: Self-tolerance checkpoints in B lymphocyte development. Adv Immunol 1995; 59:279-368.

13 Goodnow CC: Balancing immunity and tolerance: deleting and tuning lymphocyte repertoires. Proc Natl Acad Sci U S A 1996;93(6):2264-2271.

14 Stockinger B: T lymphocyte tolerance: from thymic deletion to peripheral control mechanisms. Adv Immunol 1999;71:229-265.

15 Walker LS, Abbas AK: The enemy within: keeping self-reactive $\mathrm{T}$ cells at bay in the periphery. Nat Rev Immunol 2002;2(1):11-19.

16 Rice JS, Newman J, Wang C, Michael DJ, Diamond B: Receptor editing in peripheral B cell tolerance. Proc Natl Acad Sci U S A 2005;102(5):1608-1613.

17 Prodeus AP, Goerg S, Shen LM, Pozdnyakova OO, Chu L, Alicot EM, Goodnow CC, Carroll MC: A critical role for complement in maintenance of selftolerance. Immunity 1998;9(5):721-731.

18 Sakaguchi S, Sakaguchi N, Asano M, Itoh M, Toda M: Immunologic self-tolerance maintained by activated $\mathrm{T}$ cells expressing IL-2 receptor alpha-chains (CD25). Breakdown of a single mechanism of selftolerance causes various autoimmune diseases. J Immunol 1995;155(3):1151-1164.

19 Sakaguchi S, Sakaguchi N, Shimizu J, Yamazaki S, Sakihama T, Itoh M, Kuniyasu Y, Nomura T, Toda M, Takahashi T: Immunologic tolerance maintained by $\mathrm{CD} 25+\mathrm{CD} 4+$ regulatory $\mathrm{T}$ cells: their common role in controlling autoimmunity, tumor immunity, and transplantation tolerance. Immunol Rev 2001;182:18-32.
20 Shevach EM: CD4+ CD25+ suppressor T cells: more questions than answers. Nat Rev Immunol 2002;2(6):389-400.

21 Takahashi T, Sakaguchi S: Naturally arising CD25+CD4+ regulatory $\mathrm{T}$ cells in maintaining immunologic self-tolerance and preventing autoimmune disease. Curr Mol Med 2003;3(8):693-706.

22 Nomura T, Sakaguchi S: Naturally arising CD25+ $\mathrm{CD} 4+$ regulatory $\mathrm{T}$ cells in tumor immunity. Curr Top Microbiol Immunol 2005;293:287-302.

23 You S, Slehoffer G, Barriot S, Bach JF, Chatenoud $\mathrm{L}$ : Unique role of $\mathrm{CD} 4+\mathrm{CD} 62 \mathrm{~L}+$ regulatory $\mathrm{T}$ cells in the control of autoimmune diabetes in $\mathrm{T}$ cell receptor transgenic mice. Proc Natl Acad Sci U S A 2004;101(suppl 2):14580-14585.

24 Sakaguchi S: Naturally arising Foxp3-expressing CD25+CD4+ regulatory $\mathrm{T}$ cells in immunological tolerance to self and non-self. Nat Immunol 2005;6 (4):345-352.

25 Ludewig B, Junt T, Hengartner H, Zinkernagel RM: Dendritic cells in autoimmune diseases. Curr Opin Immunol 2001;13(6):657-662.

26 Ludewig B, Krebs P, Junt T, Bocharov G: Dendritic cell homeostasis in the regulation of self-reactivity. Curr Pharm Des 2003;9(3):221-231.

27 Munn DH, Sharma MD, Lee JR, Jhaver KG, Johnson TS, Keskin DB, Marshall B, Chandler P, Antonia SJ, Burgess R, Slingluff CL, Jr., Mellor AL: Potential regulatory function of human dendritic cells expressing indoleamine 2.3-dioxygenase. Science 2002;297(5588):1867-1870

28 Mellor AL, Baban B, Chandler P, Marshall B, Jhaver K, Hansen A, Koni PA, Iwashima M, Munn DH: Cutting edge: induced indoleamine 2.3 dioxygenase expression in dendritic cell subsets suppresses T cell clonal expansion. J Immunol 2003; 171(4):1652-1655.

29 Terness P, Bauer TM, Rose L, Dufter C, Watzlik A, Simon H, Opelz G: Inhibition of allogeneic T cell proliferation by indoleamine 2.3-dioxygenase-expressing dendritic cells: mediation of suppression by tryptophan metabolites. J Exp Med 2002;196(4): 447-457.

30 Terness P, Chuang JJ, Bauer T, Jiga L, Opelz G: Regulation of human auto- and alloreactive T cells by indoleamine 2.3-dioxygenase (IDO)-producing dendritic cells: too much ado about IDO? Blood 2005;105(6):2480-2486.

31 Munn DH, Mellor AL, Rossi M, Young JW: Dendritic cells have the option to express IDO-mediated suppression or not. Blood 2005;105(6):2618.

32 Munn DH, Mellor AL: Macrophages and the regulation of self-reactive T cells. Curr Pharm Des 2003; 9(3):257-264.

33 Kim S, Poursine-Laurent J, Truscott SM, Lybarger L, Song YJ, Yang L, French AR, Sunwoo JB, Lemieux S, Hansen TH, Yokoyama WM: Licensing of natural killer cells by host major histocompatibility complex class I molecules. Nature 2005;436 (7051):709-713.

34 Terness P, Opelz G: Regulation of antibody response by an IgG-anti-Ig autoantibody occurring during alloimmunization. I. A few IgG molecules inactivate one B cell. Transplantation 1992;54(1): 88-91.

35 Terness P, Marx U, Sandilands G, Roelcke D, Welschof M, Opelz G: Suppression of anti-erythrocyte autoantibody-producing B cells by a physiological IgG-anti-F(ab')2 antibody and escape from suppression by tumour transformation; a model relevant for the pathogenesis of autoimmune haemolytic anaemia. Clin Exp Immunol 1993;93(2): 253-258.
36 Terness P, Kohl I, Hubener G, Battistutta R, Moroder L, Welschof M, Dufter C, Finger M, Hain C, Jung M, et al: The natural human IgG anti-F(ab')2 antibody recognizes a conformational $\mathrm{IgG} 1$ hinge epitope. J Immunol 1995;154(12):6446-6452.

37 Terness P, Kirschfink M, Navolan D, Dufter C, Kohl I, Opelz G, Roelcke D: Striking inverse correlation between IgG anti-F(ab')2 and autoantibody production in patients with cold agglutination. Blood 1995;85(2):548-551.

38 Terness P, Navolan D, Moroder L, Siedler F, Weyher E, Kohl I, Dufter C, Welschof M, Drugarin D Schneider F, Opelz G: A natural IgA-anti$\mathrm{F}(\mathrm{ab}$ ')2gamma autoantibody occurring in healthy individuals and kidney graft recipients recognizes an IgG1 hinge region epitope. J Immunol 1996;157 (9):4251-4257.

39 Welschof M, Terness P, Kipriyanov SM, Stanescu D, Breitling F, Dorsam H, Dubel S, Little M, Opelz G The antigen-binding domain of a human IgG-antiF(ab')2 autoantibody. Proc Natl Acad Sci U S A 1997;94(5):1902-1907.

40 Welschof M, Reineke U, Kleist C, Kipriyanov S, Little M, Volkmer-Engert R, Schneider-Mergener J, Opelz G, Terness P: The antigen binding domain of non-idiotypic human anti-F(ab')2 autoantibodies: study of their interaction with IgG hinge region epitopes. Hum Immunol 1999;60(4):282-290.

41 Kazatchkine MD, Kaveri SV: Immunomodulation of autoimmune and inflammatory diseases with intravenous immune globulin. N Engl J Med 2001; 345(10):747-755.

42 De Grandmont MJ, Racine C, Roy A, Lemieux R, Neron S: Intravenous immunoglobulins induce the in vitro differentiation of human B lymphocytes and the secretion of IgG. Blood 2003;101(8):30653073 .

43 Ravetch JV, Lanier LL: Immune inhibitory receptors. Science 2000;290(5489):84-89.

44 Samuelsson A, Towers TL, Ravetch JV: Anti-inflammatory activity of IVIG mediated through the inhibitory Fc receptor. Science 2001;291(5503): 484-486.

45 Fossati-Jimack L, Ioan-Facsinay A, Reininger L, Chicheportiche Y, Watanabe N, Saito T, Hofhuis FM, Gessner JE, Schiller C, Schmidt RE, Honjo T, Verbeek JS, Izui S: Markedly different pathogenicity of four immunoglobulin $\mathrm{G}$ isotype-switch variants of an antierythrocyte autoantibody is based on their capacity to interact in vivo with the low-affinity Fcgamma receptor III. J Exp Med 2000;191(8): 1293-1302.

46 Alarcon-Segovia D, Ruiz-Arguelles A: Antibody penetration into living cells. A new mechanism of immunologically mediated damage. Rev Invest Clin 1979;31(2):111-120.

47 Ruiz-Arguelles A, Rivadeneyra-Espinoza L, Alarcon-Segovia D: Antibody penetration into living cells: pathogenic, preventive and immuno-therapeutic implications. Curr Pharm Des 2003;9(23) 1881-1887.

48 Besredka M: Ann Inst Pasteur (Paris) 1901;15:785.

49 Metalnikoff S: Ann Inst Pasteur (Paris) 1900;9:577.

50 Jerne NK: The immune system: a web of V-domains. Harvey Lect 1974;70 Series:93-110.

51 Jerne NK: Towards a network theory of the immune system. Ann Immunol (Paris) 1974;125C (1-2):373-389.

52 Lefkovits I (ed): A Portrait of the Immune System. Scientific Publications of N K Jerne. Singapore, World Scientific Publishing, 1996.

53 Varela FJ, Coutinho A: Second generation immune networks. Immunol Today 1991;12(5):159-166. 
54 Coutinho A: Simple developmental programs of gene expression and cellular composition of lymphoid organs at the origin of natural tolerance. Res Immunol 1995;146(4-5):321-332.

55 Coutinho A: Will the idiotypic network help to solve natural tolerance? Trends Immunol 2003;24 (2):53-54.

56 Cohen IR: The cognitive paradigm and the immunological homunculus. Immunol Today 1992;13 (12):490-494.

57 Cohen IR: The cognitive principle challenges clonal selection. Immunol Today 1992;13(11):441-444.

58 Cohen IR: Discrimination and dialogue in the immune system. Semin Immunol 2000;12(3):215-219, discussion 257-344.

59 Cohen IR: Antigenic mimicry, clonal selection and autoimmunity. J Autoimmun 2001;16(3):337-340.

60 Quintana FJ, Cohen IR: The natural autoantibody repertoire and autoimmune disease. Biomed Pharmacother 2004;58(5):276-281.

61 Filion MC, Bradley AJ, Devine DV, Decary F, Chartrand P: Autoreactive T cells in healthy individuals show tolerance in vitro with characteristics similar to but distinct from clonal anergy. Eur J Immunol 1995;25(11):3123-3127.

62 Filion MC, Proulx C, Bradley AJ, Devine DV, Sekaly RP, Decary F, Chartrand P: Presence in peripheral blood of healthy individuals of autoreactive $T$ cells to a membrane antigen present on bone marrow-derived cells. Blood 1996;88(6):2144-2150.

63 Rubin RL, Kretz-Rommel A: Linkage of immune self-tolerance with the positive selection of T cells. Crit Rev Immunol 1999;19(3):199-218.

64 Kretz-Rommel A, Rubin RL: Disruption of positive selection of thymocytes causes autoimmunity. Nat Med 2000;6(3):298-305.

65 Moalem G, Leibowitz-Amit R, Yoles E, Mor F, Cohen IR, Schwartz M: Autoimmune T cells protect neurons from secondary degeneration after central nervous system axotomy. Nat Med 1999;5 (1):49-55.

66 Schwartz M, Cohen IR: Autoimmunity can benefit self-maintenance. Immunol Today 2000;21(6):265268.

67 Hayakawa K, Asano M, Shinton SA, Gui M, Allman D, Stewart CL, Silver J, Hardy RR: Positive selection of natural autoreactive B cells. Science 1999;285(5424):113-116.

68 Koenig-Marrony S, Soulas P, Julien S, Knapp AM, Garaud JC, Martin T, Pasquali JL: Natural autoreactive $\mathrm{B}$ cells in transgenic mice reproduce an apparent paradox to the clonal tolerance theory. J Immunol 2001;166(3):1463-1470.

69 Julien S, Soulas P, Garaud JC, Martin T, Pasquali JL: B cell positive selection by soluble self-antigen. J Immunol 2002;169(8):4198-4204.

70 Hayakawa K, Asano M, Shinton SA, Gui M, Wen LJ, Dashoff J, Hardy RR: Positive selection of antithy- 1 autoreactive B-1 cells and natural serum autoantibody production independent from bone marrow B cell development. J Exp Med 2003;197 (1):87-99.

71 Coutinho A, Kazatchkine MD, Avrameas S: Natural autoantibodies. Curr Opin Immunol 1995;7(6): 812-818.

72 Lacroix-Desmazes S, Kaveri SV, Mouthon L, Ayouba A, Malanchere E, Coutinho A, Kazatchkine MD: Self-reactive antibodies (natural autoantibodies) in healthy individuals. J Immunol Methods 1998;216(1-2):117-137.

73 Bendelac A, Bonneville M, Kearney JF: Autoreactivity by design: innate $\mathrm{B}$ and $\mathrm{T}$ lymphocytes. Nat Rev Immunol 2001;1(3):177-186.
74 Moalem G, Yoles E, Leibowitz-Amit R, MullerGilor S, Mor F, Cohen IR, Schwartz M: Autoimmune $\mathrm{T}$ cells retard the loss of function in injured rat optic nerves. J Neuroimmunol 2000;106(1-2): 189-197.

75 Mizrahi T, Hauben E, Schwartz M: The tissue-specific self-pathogen is the protective self-antigen: the case of uveitis. J Immunol 2002;169(10):5971-5977.

76 Wang H, Shlomchik MJ: Maternal Ig mediates neonatal tolerance in rheumatoid factor transgenic mice but tolerance breaks down in adult mice. J Immunol 1998;160(5):2263-2271.

77 Manz RA, Arce S, Cassese G, Hauser AE, Hiepe F, Radbruch A: Humoral immunity and long-lived plasma cells. Curr Opin Immunol 2002;14(4): 517-521.

78 Zouali M: B cell diversity and longevity in systemic autoimmunity. Mol Immunol 2002;38(12-13): 895-901.

79 Sprent J, Surh CD: T cell memory. Annu Rev Immunol 2002;20:551-579.

80 Dorner T, Radbruch A: Selecting B cells and plasma cells to memory. J Exp Med 2005;201(4):497499.

81 Manz RA, Hauser AE, Hiepe F, Radbruch A Maintenance of serum antibody levels. Annu Rev Immunol 2005;23:367-386.

82 Avrameas S: Natural autoantibodies: from 'horror autotoxicus' to 'gnothi seauton'. Immunol Today 1991;12(5):154-159.

83 Nobrega A, Haury M, Grandien A, Malanchere E, Sundblad A, Coutinho A: Global analysis of antibody repertoires. II. Evidence for specificity, selfselection and the immunological 'homunculus' of antibodies in normal serum. Eur J Immunol 1993; 23(11):2851-2859.

84 Vasconcellos R, Nobrega A, Haury M, Viale AC, Coutinho A: Genetic control of natural antibody repertoires: I. IgH, MHC and TCR beta loci. Eur J Immunol 1998;28(3):1104-1115.

85 Fesel C, Coutinho A: Structured reactions of serum IgM repertoires to immunization are dependent on major histocompatibility complex genes. Scand J Immunol 1999;49(3):251-257.

86 Coutinho A: Germ-line selection ensures embryonic autoreactivity and a positive discrimination of self mediated by supraclonal mechanisms. Semin Immunol 2000;12(3):205-213, discussion 257-344.

87 Coutinho A, Haas W: In vivo models of dominant T-cell tolerance: where do we stand today? Trends Immunol 2001;22(7):350-351.

88 Anderson G, Hare KJ, Jenkinson EJ: Positive selection of thymocytes: the long and winding road. Immunol Today 1999;20(10):463-468.

89 Cohen IR, Young DB: Autoimmunity, microbial immunity and the immunological homunculus. Immunol Today 1991;12(4):105-110.

90 Mouthon L, Lacroix-Desmazes S, Stahl D, Kaveri SV, Coutinho A, Kazatchkine MD: Self-reactive antibody repertoires: the ' antibody homunculus'; in Talwar GP, Nath I, Ganguly NK, Rao KSV (eds): 10th International Congress of Immunology. Bologna, Monduzzi Editore, 1999, pp 729-734.

91 Stahl D, Lacroix-Desmazes S, Mouthon L, Kaveri SV, Kazatchkine MD: Analysis of human self-reactive antibody repertoires by quantitative immunoblotting. J Immunol Methods 2000;240(1-2): 1-14.

92 Mouthon L, Nobrega A, Nicolas N, Kaveri SV, Barreau C, Coutinho A, Kazatchkine MD: Invariance and restriction toward a limited set of self-antigens characterize neonatal IgM antibody repertoires and prevail in autoreactive repertoires of healthy adults. Proc Natl Acad Sci U S A 1995;92(9):38393843.
93 Mouthon L, Haury M, Lacroix-Desmazes S, Barreau C, Coutinho A, Kazatchkine MD: Analysis of the normal human IgG antibody repertoire. Evidence that IgG autoantibodies of healthy adults recognize a limited and conserved set of protein antigens in homologous tissues. J Immunol 1995; 154(11):5769-5778

94 Mouthon L, Lacroix-Desmazes S, Nobrega A, Barreau C, Coutinho A, Kazatchkine MD: The self-reactive antibody repertoire of normal human serum IgM is acquired in early childhood and remains conserved throughout life. Scand J Immunol 1996; 44(3):243-251.

95 Lacroix-Desmazes S, Mouthon L, Coutinho A, Kazatchkine MD: Analysis of the natural human IgG antibody repertoire: life-long stability of reactivities towards self antigens contrasts with age-dependent diversification of reactivities against bacterial antigens. Eur J Immunol 1995;25(9):25982604.

96 Lacroix-Desmazes S, Mouthon L, Kaveri SV, Kazatchkine MD, Weksler ME: Stability of natura self-reactive antibody repertoires during aging. J Clin Immunol 1999;19(1):26-34.

97 Lacroix-Desmazes S, Resnick I, Stahl D, Mouthon L, Espanol T, Levy J, Kaveri SV, Notarangelo L, Eibl M, Fischer A, Ochs H, Kazatchkine MD: Defective self-reactive antibody repertoire of serum $\mathrm{IgM}$ in patients with hyper-IgM syndrome. $\mathrm{J}$ Immunol 1999;162(9):5601-5608.

98 Stahl D, Lacroix-Desmazes S, Misra N, Karmochkine M, Kaveri SV, Costagliola D, Sibrowsk W, Kazatchkine MD: Alterations of self-reactive antibody repertoires in HIV disease: An insigh into the role of $\mathrm{T}$ cells in the selection of autoreactive B cells. Immunol Lett 2005;99(2):198-208.

99 Sundblad A, Marcos M, Huetz F, Freitas A, Heusser C, Portnoi D, Coutinho A: Normal serum immunoglobulins influence the numbers of bone marrow pre-B and B cells. Eur J Immunol 1991; 21(5): 1155-1161.

100 Baker N, Ehrenstein MR: Cutting Edge: Selection of B Lymphocyte Subsets Is Regulated by Natural IgM. J Immunol 2002;169(12):6686-6690.

101 Nielsen CH, Leslie RG, Jepsen BS, Kazatchkine MD, Kaveri SV, Fischer E: Natural autoantibodies and complement promote the uptake of a self antigen, human thyroglobulin, by B cells and the proliferation of thyroglobulin-reactive CD4(+) T cells in healthy individuals. Eur J Immunol 2001;31 (9):2660-2668.

102 Aktas O, Zipp F: Regulation of self-reactive T cells by human immunoglobulins- implications for multiple sclerosis therapy. Curr Pharm Des 2003;9 (3):245-256.

103 Cartron JP, Colin Y: Structural and functional diversity of blood group antigens. Transfus Clin Biol 2001;8(3):163-199.

104 Oldenborg PA, Zheleznyak A, Fang YF, Lagenaur CF, Gresham HD, Lindberg FP: Role of CD47 as a marker of self on red blood cells. Science 2000;288 (5473):2051-2054.

105 Oldenborg PA: Role of CD47 in erythroid cells and in autoimmunity. Leuk Lymphoma 2004;45 (7):1319-1327.

106 Oldenborg PA, Gresham HD, Lindberg FP CD47-signal regulatory protein alpha (SIRPalpha) regulates Fcgamma and complement receptor-mediated phagocytosis. J Exp Med 2001;193(7): 855-562.

107 Lutz HU, Flepp R, Stammler P, Baccala R: Red cell associated, naturally occurring anti-spectrin antibodies. Clin Exp Immunol 1987;67(3):674-676.

108 Lutz HU: Naturally occurring anti-band 3 antibodies. Transfus Med Rev 1992;6(3):201-211. 
109 Spalter SH, Kaveri SV, Bonnin E, Mani JC, Cartron JP, Kazatchkine MD: Normal human serum contains natural antibodies reactive with autologous ABO blood group antigens. Blood 1999;93(12):4418-4424.

110 Gehrs BC, Friedberg RC: Autoimmune hemolytic anemia. Am J Hematol 2002;69(4):258-271.

-111 Engelfriet CP, Overbeeke MA, von dem Borne AE: Autoimmune hemolytic anemia. Semin Hematol 1992;29(1):3-12.

112 Garratty G: Autoimmune hemolytic anemia, in Garratty G (ed): Immunobiology of Transfusion Medicine. New York, Marcel Dekker, 1994, pp 493.

113 Meyer D, Schiller C, Westermann J, Izui S, Hazenbos WL, Verbeek JS, Schmidt RE, Gessner JE: FcgammaRIII (CD16)-deficient mice show IgG isotype-dependent protection to experimental autoimmune hemolytic anemia. Blood 1998;92(11) 3997-4002.

114 Fossati-Jimack L, Reininger L, Chicheportiche Y, Clynes R, Ravetch JV, Honjo T, Izui S: High pathogenic potential of low-affinity autoantibodies in experimental autoimmune hemolytic anemia. J Exp Med 1999;190(11):1689-1696.

115 Schiller C, Janssen-Graalfs I, Baumann U, Schwerter-Strumpf K, Izui S, Takai T, Schmidt RE, Gessner JE: Mouse FcgammaRII is a negative regulator of FcgammaRIII in IgG immune complex-triggered inflammation but not in autoantibody-induced hemolysis. Eur J Immunol 2000;30 (2):481-490.

116 Izui S, Fossati-Jimack L, da Silveira SA, Moll T: Isotype-dependent pathogenicity of autoantibodies: analysis in experimental autoimmune hemolytic anemia. Springer Semin Immunopathol 2001;23(4):433-445

-117 Azeredo da Silveira S, Kikuchi S, Fossati-Jimack L, Moll T, Saito T, Verbeek JS, Botto M, Walport MJ, Carroll M, Izui S: Complement activation selectively potentiates the pathogenicity of the $\mathrm{IgG} 2 \mathrm{~b}$ and $\mathrm{IgG} 3$ isotypes of a high affinity antierythrocyte autoantibody. J Exp Med 2002;195(6): 665-672.

-118 Sano H, Hsu DK, Apgar JR, Yu L, Sharma BB, Kuwabara I, Izui S, Liu FT: Critical role of galectin-3 in phagocytosis by macrophages. J Clin Invest 2003;112(3):389-397.

-119 Barker RN, Casswell KM, Reid ME, Sokol RJ, Elson CJ: Identification of autoantigens in autoimmune haemolytic anaemia by a non-radioisotope immunoprecipitation method. $\mathrm{Br} \mathrm{J}$ Haematol 1992;82(1):126-132.
120 Leddy JP, Falany JL, Kissel GE, Passador ST, Rosenfeld SI: Erythrocyte membrane proteins reactive with human (warm-reacting) anti-red cell autoantibodies. J Clin Invest 1993;91(4):16721680.

121 Shen CR, Youssef AR, Devine A, Bowie L, Hall AM, Wraith DC, Elson CJ, Barker RN: Peptides containing a dominant T-cell epitope from red cell band 3 have in vivo immunomodulatory properties in NZB mice with autoimmune hemolytic anemia. Blood 2003;102(10):3800-386.

122 Issitt PD, Zellner DC, Rolih SD, Duckett JB: Autoantibodies mimicking alloantibodies. Transfusion 1977;17(6):531-538

123 Garratty G: The significance of IgG on the red cell surface. Transfus Med Rev 1987;1(1):47-57.

124 Adib M, Ragimbeau J, Avrameas S, Ternynck T: IgG autoantibody activity in normal mouse serum is controlled by IgM. J Immunol 1990;145(11): 3807-3813.

125 Hurez V, Kaveri SV, Kazatchkine MD: Expression and control of the natural autoreactive IgG repertoire in normal human serum. Eur J Immunol 1993;23(4):783-789.

126 Boes M, Esau C, Fischer MB, Schmidt T, Carroll M, Chen J: Enhanced B-1 cell development, but impaired $\mathrm{IgG}$ antibody responses in mice deficient in secreted IgM. J Immunol 1998;160(10):47764787.

127 Boes M, Schmidt T, Linkemann K, Beaudette BC, Marshak-Rothstein A, Chen J: Accelerated development of $\mathrm{IgG}$ autoantibodies and autoimmune disease in the absence of secreted IgM. Proc Natl Acad Sci U S A 2000;97(3):1184-1189.

128 Ehrenstein MR, Cook HT, Neuberger MS: Deficiency in serum immunoglobulin (Ig)M predisposes to development of IgG autoantibodies. J Exp Med 2000;191(7):1253-1258.

129 Hentati B, Payelle-Brogard B, Jouanne C, Avrameas S, Ternynck T: Natural autoantibodies are involved in the haemolytic anaemia of NZB mice. J Autoimmun 1994;7(4):425-439.

130 Stahl D, Lacroix-Desmazes S, Heudes D, Mouthon L, Kaveri SV, Kazatchkine MD: Altered control of self-reactive $\mathrm{IgG}$ by autologous $\mathrm{IgM}$ in patients with warm autoimmune hemolytic anemia. Blood 2000;95(1):328-335.

131 Stahl D, Lacroix-Desmazes S, Kaveri SV, Kazatchkine MD: Polyreactivity of disease-associated anti-RBC $\operatorname{IgG}$ autoantibodies of patients with warm autoimmune haemolytic anaemia and natural anti-RBC IgG autoantibodies of healthy individuals. Scand J Immunol 2000;52(2):190-199.

132 Stahl D, Sibrowski W: Warm autoimmune hemolytic anemia is an immune complex disease. $\mathrm{J}$ Autoimmun;2005;25(4):272-282.
133 Park YH, Miyama-Inaba M, Suzuki T, Masuda T, Yoshida Y, Uchino H: Immunological characterization of FcR gamma bearing and nonbearing $\mathrm{B}$ cells: functional modulation of immune complexes. Cell Immunol 1984;83(2):340-350.

134 Heyman B: Regulation of antibody responses via antibodies, complement, and Fc receptors. Annu Rev Immunol 2000;18:709-737.

135 Sakamoto N, Shibuya K, Shimizu Y, Yotsumoto K, Miyabayashi T, Sakano S, Tsuji T, Nakayama E, Nakauchi H, Shibuya A: A novel Fc receptor for $\operatorname{IgA}$ and $\operatorname{IgM}$ is expressed on both hematopoietic and non-hematopoietic tissues. Eur J Immunol 2001;31(5):1310-1316.

136 Heyman B: The immune complex: possible ways of regulating the antibody response. Immunol Today 1990;11(9):310-3.

137 Hamano Y, Arase H, Saisho H, Saito T: Immune complex and $\mathrm{Fc}$ receptor-mediated augmentation of antigen presentation for in vivo Th cell responses. J Immunol 2000;164(12):6113-6119.

138 Kumpel BM, Elson CJ: Mechanism of anti-D-mediated immune suppression - a paradox awaiting resolution? Trends Immunol 2001;22(1):26-31.

139 Erdei A, Prechl J, Isaak A, Molnar E: Regulation of B-cell activation by complement receptors CD21 and CD35. Curr Pharm Des 2003;9(23): 1849-60.

140 Heyman B: Feedback regulation by IgG antibodies. Immunol Lett 2003;88(2):157-61.

141 Kalergis AM: Modulation of T cell immunity by TCR/pMHC dwell time and activating/inhibitory receptor pairs on the antigen-presenting cell. Curr Pharm Des 2003;9(3):233-244.

142 Leadbetter EA, Rifkin IR, Hohlbaum AM, Beaudette BC, Shlomchik MJ, Marshak-Rothstein A: Chromatin-IgG complexes activate B cells by dual engagement of IgM and Toll-like receptors. Nature 2002;416(6881):603-7.

143 Haberman AM, William J, Euler C, Shlomchik MJ: Rheumatoid factors in health and disease: structure, function, induction and regulation, in Nemazee D (ed): B Cell Biology in Autoimmunity. Curr Dir Autoimmun. Basel, Karger, 2003, vol 6, pp 169-195.

144 Wang S, Yang T, Zhang J, Xiao S, Peng X: Analysis of Ig/Ig two-component-determined circulating immune complexes (TCIC) provide new insights into host immunity. Int Immunopharmacol 2003; 3(10-11):1549-1555.

145 Roux KH, Strelets L, Michaelsen TE: Flexibility of human IgG subclasses. J Immunol 1997;159(7): 3372-3382.

146 Roux KH, Strelets L, Brekke OH, Sandlie I, Michaelsen TE: Comparisons of the ability of human IgG3 hinge mutants, IgM, IgE, and IgA2, to form small immune complexes: a role for flexibility and geometry. J Immunol 1998;161(8): 4083-4090. 